\title{
Phenotypic analysis of cheese yields and nutrient recoveries in the curd of buffalo milk, as measured with an individual model cheese-manufacturing process
}

\author{
C. Cipolat-Gotet, G. Bittante, and A. Cecchinato ${ }^{1}$ \\ Department of Agronomy, Food, Natural Resources, Animals and Environment (DAFNAE), University of Padova, \\ Viale dell'Università 16-35020 Legnaro (PD), Italy
}

\begin{abstract}
Traits associated with cheese yield and milk nutrient recovery in curd are used to describe the efficiency of the cheese-making process. This is fundamental for all dairy species, including the Italian Mediterranean buffalo, which is largely used for milk production aimed at the dairy industry. To assess cheese-making traits among buffalo, a model cheese-manufacturing process was tested; it was capable of processing 24 samples per run, using 0.5-L samples of milk from individual buffalo. In total, 180 buffalo reared in 7 herds located in Northeast Italy were sampled once. Briefly, each sample was weighed and heated $\left(35^{\circ} \mathrm{C}\right.$ for $\left.30 \mathrm{~min}\right)$, inoculated with starter culture (90 min), and mixed with rennet (51.2 international milk-clotting units/L of milk). After 10 min of gelation, the curd was cut; 5 min after the cut, the curd was separated from the whey, and the curd was subjected to draining (for $30 \mathrm{~min}$ ) and pressing $(18 \mathrm{~h})$. The curd and whey were weighed, analyzed for $\mathrm{pH}$ and the total solid, fat, lactose, and protein contents, and subjected to estimation of the energy content. Three measures of cheese yield $(\% \mathrm{CY}), \% \mathrm{CY}-$ CURD, $\% \mathrm{CY}_{\text {SOLIDS }}$, and $\% \mathrm{CY}_{\text {WATER }}$, were computed as the ratios between the weight of the curd, the curd dry matter, and the water retained in the curd, respectively, and the weight of the milk processed. These traits were multiplied by the daily milk yield to define the 3 corresponding measures of daily cheese yield $(\mathrm{dCY}, \mathrm{kg} / \mathrm{d})$. The milk component recoveries (REC) in the curd, $\mathrm{REC}_{\mathrm{FAT}}, \mathrm{REC}_{\mathrm{PROTEIN}}$, and $\mathrm{REC}_{\text {SOLIDS }}$, represented the ratios between the weights of the fat, protein, and total solids in the curd, respectively, and the corresponding components in the milk. Finally, energy recovery $\left(\mathrm{REC}_{\text {ENERGY }}\right)$ was estimated. The values for $\% \mathrm{CY}_{\mathrm{CURD}}$, $\% \mathrm{CY}_{\text {SOLIDS }}, \% \mathrm{CY}_{\text {WATER }}, \mathrm{REC}_{\text {PROTEIN }}, \mathrm{REC}_{\mathrm{FAT}}, \mathrm{REC}-$ SOLIDS, and $\mathrm{REC}_{\text {ENERGY }}$ averaged $25.6,12.7,12.9,80.4$, $95.1,66.7$, and $79.3 \%$, respectively, indicating that buf-
\end{abstract}

Received April 30, 2014.

Accepted October 11, 2014.

${ }^{1}$ Corresponding author: alessio.cecchinato@unipd.it falo milk has a higher aptitude to cheese-making than bovine milk. The effect of days in milk was the most important source of variation for $\% \mathrm{CY}, \mathrm{REC}_{\text {PROTEIN }}$, and the overall recoveries (which showed higher values toward the end of lactation), whereas parity did not appear to influence any of the investigated traits. The cheese-making procedure tested allowed us to assess the variability of and relationships among different cheese yield traits, recovery traits, daily milk production traits, and milk components at the individual level.

Key words: buffalo milk, cheese-making trait, individual cheese yield, whey loss

\section{INTRODUCTION}

The buffalo (Bubalus bubalis) is the second most important dairy species, providing $13 \%$ of the total milk produced worldwide (FAOSTAT, 2014). In Italy, the Mediterranean buffalo breed has been selected for milk production and quality. Traditionally, buffalo dairy farms are concentrated in Southern Italy, where "Mozzarella di Bufala Campana," an Italian protected designation of origin (PDO) cheese, is produced; however, the buffalo population has expanded to different regions of the country in recent years (Tiezzi et al., 2009). In fact, the Italian buffalo population, registered in national the herd book, has increased by $36 \%$ over the past decade (ANASB, 2013), mainly because of the absence of a quota system for milk production and the higher price of buffalo milk.

Currently, the selection program of the National Association of Buffalo Breeders is based on the PKM index, which estimates the mozzarella cheese $(\mathrm{kg})$ produced per lactation (Rosati and Van Vleck, 2002) by using formulas to predict cheese yield (\%CY), as introduced by Altiero et al. (1989). The prediction equations used to estimate \%CY are normally based on the contents of milk protein (or its fractions) and fat (Van Slyke and Price, 1952; Banks et al., 1981; Emmons et al., 1990), and assume that their recoveries in the curd are constant. However, in an analysis of model cheeses made from individual milk samples, Cipolat- 
Gotet et al. (2013) demonstrated that the whey losses/ curd recoveries (REC) of bovine milk components were not constant, and were influenced by individual causes of variation (e.g., the stage of lactation and order of parity). Using the same dataset, Bittante et al. (2013a) observed that both \%CY and REC are genetically controlled, whereas Ferragina et al. (2013) proposed that Fourier-transform infrared spectroscopy-based predictions could be used to monitor the cheese-making ability of cow milk at the individual level. Zicarelli et al. (2007a) estimated \%CY from individual buffalo milk samples, and showed higher values for actual \%CY compared with those predicted (Altiero et al., 1989). Although a few studies have examined the \% $\mathrm{CY}$ of buffalo milk (Di Palo et al., 2007; Napolano et al., 2007; Zicarelli et al., 2007b), the cheese-making efficiency of buffalo milk has not been fully investigated at the individual level, and no previous study has elucidated the factors that affect the variability of nutrient recovery in the cheese/loss in the whey in this system.

Given these gaps in the literature, the present study sought (1) to characterize individual buffalo \% CY and REC (protein, fat, solids, and energy) in the curd using a model cheese-manufacturing process; (2) to estimate the daily production of cheese $(\mathbf{d C Y} ; \mathrm{kg} / \mathrm{d})$ at the individual level; (3) to compare the cheese-making aptitude of buffalo milk versus that of cow milk; and (4) to investigate several potential sources of variation for these traits using individual model cheeses made from buffalo milk.

\section{MATERIALS AND METHODS}

\section{Data Collection and Analysis}

Milk samples were collected once from 180 buffalo cows reared in 7 herds located in Northeast Italy (Veneto and Friuli-Venezia Giulia regions) between December and April. Buffaloes were selected from each herd to represent the entire lactation and different parity order. During the evening milking, an individual milk sample from each buffalo was collected (in a stainless-steel vat; sampling of 1,000 L of milk/buffalo, divided in 2 disposable plastic containers, both of $500-\mathrm{mL}$ capacity) without preservative. All samples were immediately cooled to $4^{\circ} \mathrm{C}$, stored in portable refrigerators $\left(4^{\circ} \mathrm{C}\right)$ and transferred to the Milk Laboratory of the Department of Agriculture, Food, Natural Resources, Animals and Environment (University of Padova, Legnaro, Italy). All the samples were analyzed within $20 \mathrm{~h}$ after collection.

From one subsample, $50 \mathrm{~mL}$ was used to measure milk quality traits (total solids, fat, protein, casein, and lactose) by using a MilkoScan FT2 (Foss, Hillerød,
Denmark). The SCC of each sample was obtained using a Fossomatic FC counter (Foss) and log-transformed to SCS, as proposed by Ali and Shook (1980). All the samples were analyzed after heating to $35^{\circ} \mathrm{C}$. Data on the buffaloes, herds, and single test-day milk yield were provided by the breeders' associations of the Veneto (Associazione Regionale Allevatori del Veneto) and Friuli Venezia-Giulia (Associazione Allevatori del Fruili Venezia Giula) regions.

\section{Individual Model Cheese-Manufacturing Procedure}

A laboratory micro cheese-making method previously proposed for the assessment of \% $\mathrm{CY}$ and the recovery of milk constituents in the curd (Cologna et al., 2009) was used to process the individual buffalo milk samples. The cheese-making apparatus consisted of 3 water baths (WB) fitted with a digital temperature controller and water pumps to ensure homogeneous heat distribution. Each WB received 8 stainless steel vats (capacity, $500 \mathrm{~mL}$ ); thus, the apparatus allowed us to process up to 24 individual milk samples $(3 \mathrm{WB} \times 8$ vats) per cheese-making session (1 d).

Each buffalo milk sample $(500 \mathrm{~mL})$ was subjected to the following procedure (Figure 1). The milk was heated to $35^{\circ} \mathrm{C}$ (30 min), and after the reaching of this temperature, the $\mathrm{pH}$ was recorded using a Crison Basic 20 electrode (Crison, Barcelona, Spain), and starter cultures were inoculated into the samples. The starter cultures consisted of an industrial freeze-dried formulation of thermophilic lactic bacteria (Delvo-Tec TS-10A DSL; DSM Food Specialties, Delft, the Netherlands); the cultures were concentrated to 8-fold higher than the recommended level, to reduce the acidification time to $90 \mathrm{~min}$, and calf rennet solution $[3.2 \mathrm{~mL}$ per sample, consisting of $0.16 \mathrm{~mL}$ of Hansen standard 160, $80 \pm 5 \%$ chymosin, and $20 \pm 5 \%$ pepsin; 160 international milk clotting units/mL (Pacovis Amrein AG, Bern, Switzerland) diluted 20-fold in distilled water] was added. Ten minutes after the operator observed the initiation of milk gelation, the curd was cut into cubes of about 0.5 $\mathrm{cm}^{3}$. Five minutes after the cut, the curd was separated from the whey and suspended over the whey-containing vat in a stainless-steel cheese mold. Thirty minutes later, the curd was turned, and then it was pressed for $18 \mathrm{~h}$ at room temperature using a $1-\mathrm{kg}$ weight.

After pressing, the curd and whey were weighed (g) and the whey components (total solids, fat, protein, lactose) and acidity $(\mathrm{pH})$ were determined using a MilkoScan FT2 (Foss, Hillerød, Denmark) and a Crison Basic 20 electrode (Crison, Barcelona, Spain), respectively. These data were used to calculate various cheese-making efficiency traits, as previously described by Cipolat-Gotet et al. (2013). Briefly, \% CY $_{\text {CURD, }}$ 


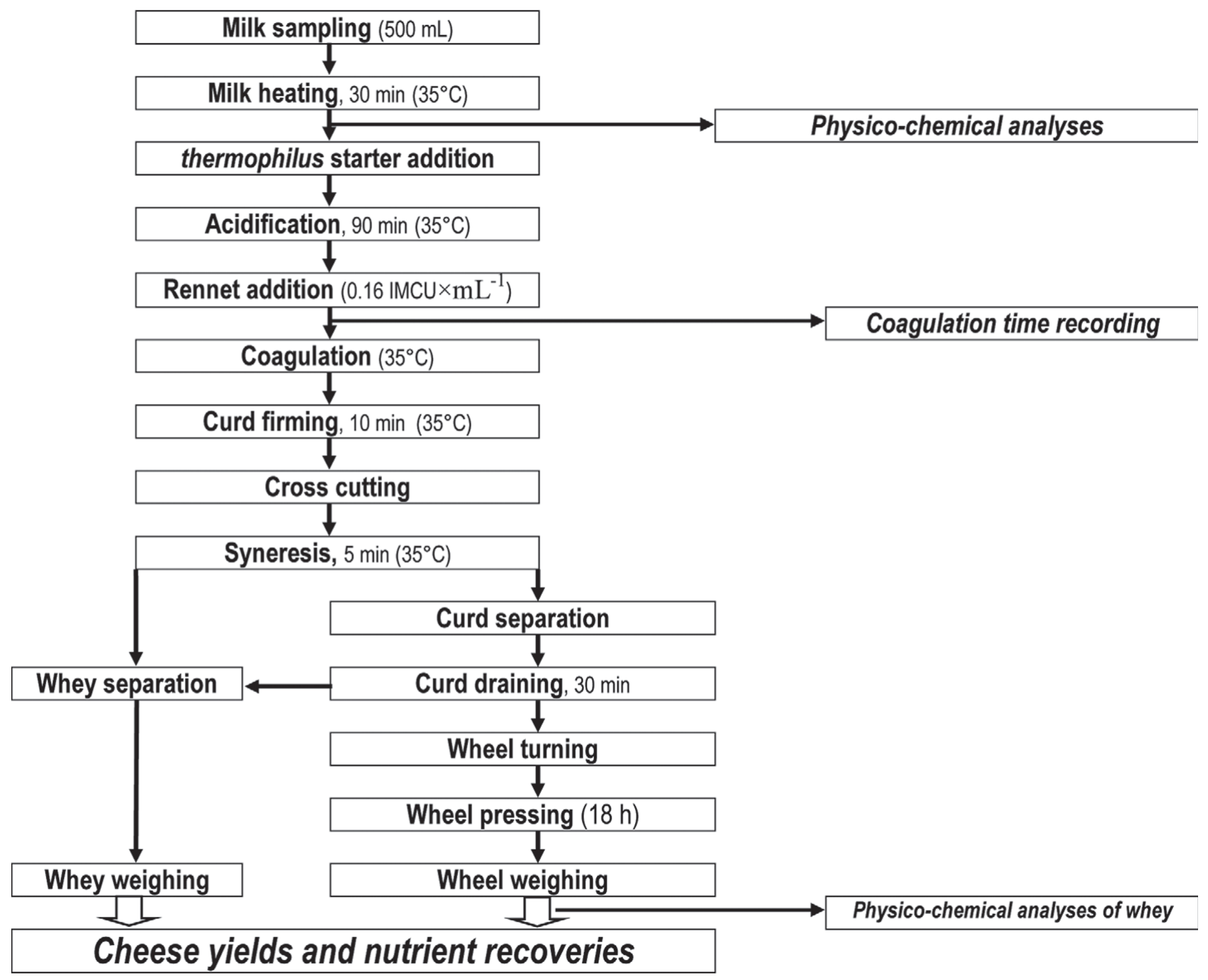

Figure 1. Flowchart for the micro model cheese-making.

$\mathbf{\%} \mathbf{C Y}_{\text {SOLIDS }}$, and $\mathbf{\%} \mathbf{C Y} \mathbf{Y A T E R}_{\text {WATe }}$ werlculated as the ratios of the weight (wt, g) of the fresh curd, curd dry matter, and curd water, respectively, versus the weight of the processed milk (g): percentage cheese yield $\left(\% \mathrm{CY}_{\text {CURD }}\right)$ as wt of curd $\times 100 /$ wt of milk; percentage TS cheese yield $\left(\% \mathrm{CY}_{\text {SOLIDS }}\right)$ as (wt of milk TS - wt of whey TS $\times 100 /$ wt of milk; percentage water cheese yield $\left(\% \mathrm{CY}_{\text {WATER }}\right)$ as (wt of milk water - wt of whey water) $\times 100 /$ wt of milk. The $\mathbf{R E C}_{\text {ProteIN }}, \mathbf{R E C}_{\mathrm{FAT}}$, and $\mathbf{R E C} \mathbf{C}_{\text {Solids }}$ were calculated as the ratios of the weight (g) of the curd component (protein, fat, and dry matter, respectively) versus that of the same component in the processed milk $(\mathrm{g})$ : fat recovery $\left(\mathrm{REC}_{\mathrm{FAT}}\right.$, $\%)$ as (wt of milk fat - wt of whey fat) $\times 100 /$ wt of milk fat; protein recovery $\left(\mathrm{REC}_{\text {PROTEIN }}, \%\right.$ ) as (wt of milk protein - wt of whey protein) $\times 100 /$ wt of milk protein; TS recovery $\left(\mathrm{REC}_{\text {SOLIDS }}, \%\right)$ as (wt of milk TS - wt of whey TS $) \times 100 /$ wt of milk TS. Recovery

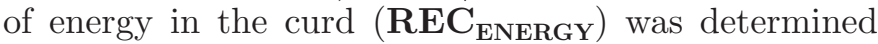
by estimating the energies of the milk and curd using the equation previously described by the NRC (2001), and converting the results to $\mathrm{MJ} / \mathrm{kg}$ : $\mathrm{REC}_{\text {ENERGY }}(\%)$ as (milk energy - whey energy) $\times 100 /$ milk energy. Lastly, the daily cheese yields $\left(\mathbf{d} \mathbf{C Y}_{\mathbf{C U R D}}, \mathbf{d C Y}_{\text {SOLIDS }}\right.$, and $\mathbf{d} \mathbf{C Y} \mathbf{Y}_{\text {WATER }} ; \mathrm{kg} / \mathrm{d}$ ) were calculated by multiplying the different \%CY values (curd, DM, and water, respectively) by the daily milk yield (MY; $\mathrm{kg} / \mathrm{d}$ ): daily cheese yield $\left(\mathrm{dCY}_{\mathrm{CURD}}, \mathrm{kg} / \mathrm{d}\right)$ as $\% \mathrm{CY}_{\mathrm{CURD}} \times$ daily milk yield of a cow $(\mathbf{d M Y}, \mathrm{kg} / \mathrm{d}) \times 0.01$; daily TS cheese yield $\left(\mathrm{dCY}_{\text {SOLIDS }}, \mathrm{kg} / \mathrm{d}\right)$ as $\% \mathrm{CY}_{\text {SOLIDS }} \times \mathrm{dMY} \times$ 0.01 ; and daily water cheese yield ( $\left.\mathrm{dCY}_{\mathrm{WATER}}, \mathrm{kg} / \mathrm{d}\right)$ as $\% \mathrm{CY}_{\text {WATER }} \times \mathrm{dMY} \times 0.01$. 


\section{Statistical Analysis}

The sources of variation for the aforementioned traits (\% CY and REC) were analyzed using the MIXED procedure (SAS Institute Inc., Cary, NC) according to the following linear model:

$$
\begin{aligned}
y_{i j k l m n}=\mu & +\operatorname{DIM}_{i}+\text { parity }_{j}+\text { vat } / \text { waterbath }_{k} \\
& +\mathrm{dMY}_{l}+\operatorname{Herd}_{m}+e_{i j k l m n},
\end{aligned}
$$

where $y_{i j k l m n}$ is the observed trait $\left(\% \mathrm{CY}_{\mathrm{CURD}}, \% \mathrm{CY} \mathrm{Y}_{\mathrm{SOL}-}\right.$ IDS, $\% \mathrm{CY}_{\text {WATER }}, \mathrm{REC}_{\text {PROTEIN }}, \mathrm{REC}_{\mathrm{FAT}}, \mathrm{REC}_{\text {SOLIDS }}$, RE$\left.\mathrm{C}_{\text {ENERGY }}\right) ; \mu$ is the overall intercept of the model; $\mathrm{DIM}_{i}$ is the fixed effect of the $i$ th class of DIM ( $\mathrm{i}=1$ to 6 ; class $1,<60 \mathrm{~d}$; class 2,60 to $110 \mathrm{~d}$; class 3,111 to 160 d; class 4, 161 to $210 \mathrm{~d}$; class 5, 211 to $260 \mathrm{~d}$; class 6 , $>260 \mathrm{~d}$ ); parity $_{j}$ is the fixed effect of the $j$ th parity of the buffaloes ( $\mathrm{j}=1$ to 5 or more); vat/waterbath is the fixed effect of the $k$ th number of the vat within each WB $(\mathrm{k}=1$ to 24$) ; \mathrm{dMY}_{l}$ is the fixed effect of $l$ th class of single test-day milk yield $(l=1$ to 7 ; class $1 \leq 3.60$; class $2,3.61$ to 5.20 ; class $3,5.21$ to 6.80 ; class $4,6.81$ to 8.40 ; class 5, 8.41 to 10.00 ; class $6,10.01$ to 11.60 ; class $7 \geq 11.61$ ); Herd $_{m}$ is the random effect of the $m$ th herd/test day ( $\mathrm{m}=1$ to 7 ); and $e_{i j k l m n}$ is the random residual. The herd/test day (HTD) and residuals were assumed to be independently and normally distributed with a mean equal to zero and variances of $\sigma_{H}^{2}$ and $\sigma_{e}^{2}$, respectively. The percentage of variance explained by HTD was calculated by dividing the corresponding component of variance by the total variance.

To analyze dMY, we used the same linear model without the including vat/waterbath and dMY effects. For dCY, we excluded the vat/waterbath effect as an explicatory variable. Orthogonal contrasts were estimated between the least squares means of the cheesemaking traits for the effects of parity (primiparous vs. pluriparous buffaloes) and daily milk production (linear, quadratic, and cubic components).

\section{RESULTS}

\section{Means and Phenotypic Variation}

The descriptive statistics for the milk, whey, and curd quality traits are summarized in Table 1 . The mean fat, protein, casein, and lactose contents of buffalo milk were $8.54,4.80,3.98$, and $4.93 \%$, respectively, yielding (along with ash) a mean milk TS content of $18.96 \%$. The SCS value averaged 4.05 and showed a typically high coefficient of variation (49.87\%). The whey composition (\%) included $0.57 \%$ fat and $1.26 \%$ protein; lactose $(5.50 \%)$ was the largest contributor to the whey TS of $8.45 \%$. The fresh curd had average contents of 49.70, 31.43, 15.19, and $3.22 \%$ for TS, fat, protein, and lactose, respectively. Regarding CV, fat (42.27\%) and protein (16.85\%) had the highest CVs in the whey, whereas lactose had the highest CV (34.13\%) in the curd.

The mean values and standard deviations of the \%CY, REC, and $\mathrm{dCY}$ are given in Table 2. The \%CYCURD, $\% \mathrm{CY}_{\text {SOLIDS }}$, and $\% \mathrm{CY}_{\text {WATER }}$ from the buffalo milk samples averaged 25.6, 12.7, and $12.9 \%$, respectively. The standard deviations were high, reflecting high variabilities for these traits. Dry matter (TS, \%) and water each represented approximately one-half of the total yield of curd (Table 1). The individual-level recoveries of milk nutrients in the curd averaged 80.4, 95.1, 66.7, and $79.3 \%$ for $\mathrm{REC}_{\text {PROTEIN }}, \mathrm{REC}_{\mathrm{FAT}}, \mathrm{REC}_{\text {SOLIDS }}$, and $\mathrm{REC}_{\text {ENERGY }}$, respectively (Table 2 ). The variability was relatively high for all REC traits. The buffalo \%CY and REC traits all showed normal distributions with kurtosis and skewness values (estimated using model residuals) close to 0 (data not shown). The daily yield traits (Table 2) exhibited low average values for dMY. However, the dCY were relatively high, reflecting the high \%CY of buffalo milk.

\section{Correlations Among Traits}

The Pearson product-moment correlations among the different cheese-making traits above the diagonal

Table 1. Descriptive statistics of milk, whey, and curd composition and acidity, and of milk SCS

\begin{tabular}{lrrrrrrrr}
\hline & \multicolumn{3}{c}{ Milk } & & \multicolumn{2}{c}{ Whey } & & \multicolumn{2}{c}{ Curd } \\
\cline { 2 - 3 } \cline { 8 - 9 } Trait & Mean & CV & & Mean & CV & & Mean & CV \\
\hline TS, \% & 18.96 & 11.67 & & 8.33 & 8.28 & & 49.70 & 8.11 \\
Fat, \% & 8.54 & 23.03 & & 0.57 & 42.27 & & 31.43 & 12.42 \\
Protein, \% & 4.80 & 11.89 & & 1.26 & 16.85 & & 15.19 & 9.79 \\
Lactose, \% & 4.93 & 7.18 & & 5.50 & 8.45 & & 3.22 & 34.13 \\
pH & 6.71 & 1.98 & & 5.70 & 10.76 & & 5.10 & 2.34 \\
SCS, units & 4.05 & 49.87 & & - & - & & - & - \\
\hline
\end{tabular}

${ }^{1} \mathrm{SCS}=\log _{2}(\mathrm{SCC} \times 100,000)+3$. 
Table 2. Descriptive statistics of individual percentage cheese yield (\%CY; weight of fresh curd, curd solids, and curd water as percentage of weight of milk processed), milk nutrient recovery (REC; protein, fat, solids, and energy of the curd as percentage of the protein, fat, solids, and energy of the milk processed), daily production (dCY; curd, curd solids, and curd water produced) of buffalo milk compared with cow milk

\begin{tabular}{|c|c|c|c|c|}
\hline \multirow[b]{2}{*}{ Trait } & \multicolumn{2}{|c|}{$\begin{array}{l}\text { Buffalo milk } \\
\text { (present study) }\end{array}$} & \multicolumn{2}{|c|}{$\begin{array}{c}\text { Cow milk } \\
\text { (Bittante et al., 2013a) }\end{array}$} \\
\hline & Mean & $\mathrm{SD}$ & Mean & $\mathrm{SD}$ \\
\hline \multicolumn{5}{|c|}{ Cheese yield, \% } \\
\hline$\% \mathrm{CY}_{\mathrm{CURD}}$ & 25.6 & 3.8 & 15.0 & 1.9 \\
\hline$\% \mathrm{CY}_{\text {SOLIDS }}$ & 12.7 & 2.3 & 7.2 & 0.9 \\
\hline$\% \mathrm{CY}_{\text {WATER }}$ & 12.9 & 1.9 & 7.8 & 1.3 \\
\hline \multicolumn{5}{|c|}{ Nutrient recovery, $\%$} \\
\hline REC $_{\text {PROTEIN }}$ & 80.4 & 2.3 & 78.1 & 2.4 \\
\hline $\mathrm{REC}_{\mathrm{FAT}}$ & 95.1 & 1.8 & 89.8 & 3.6 \\
\hline $\mathrm{REC}_{\text {SOLIDS }}$ & 66.7 & 5.1 & 51.9 & 3.5 \\
\hline REC $_{\text {ENERGY }}$ & 79.3 & 3.5 & 67.2 & 3.3 \\
\hline \multicolumn{5}{|c|}{ Production trait, $\mathrm{kg} / \mathrm{d}$} \\
\hline Milk yield & 7.60 & 3.19 & 24.62 & 7.63 \\
\hline $\mathrm{dCY}_{\mathrm{CURD}}$ & 1.92 & 0.72 & 3.63 & 1.13 \\
\hline $\mathrm{dCY}_{\text {SOLIDS }}$ & 0.96 & 0.35 & 1.74 & 0.57 \\
\hline $\mathrm{dCY}_{\text {WATER }}$ & 0.97 & 0.39 & 1.88 & 0.64 \\
\hline
\end{tabular}

and correlations among residuals below the diagonal are presented in Table 3 . The correlations between different \%CY were high and positive $(P<0.001)$. They were particularly high when $\% \mathrm{CY}_{\mathrm{CURD}}$ was related to $\% \mathrm{CY}_{\text {SOLIDS }}$ and $\% \mathrm{CY}_{\text {WATER }}$ (82 to $90 \%$ ), and more moderate when the curd components (DM and water) were correlated to each other (53 and $44 \%$ for the raw data and residuals, respectively). For the recoveries, the Pearson correlation between $\mathrm{REC}_{\text {PROTEIN }}$ and $\mathrm{REC}_{\mathrm{FAT}}$ was low $(18 \% ; P<0.05)$ and the residual correlation was not significant, suggesting that the recovery of these 2 components in the curd is almost independent. The recoveries of fat and protein in curd were moderately correlated to $\mathrm{REC}_{\text {SOLIDS }}$ and $\mathrm{REC}_{\text {ENERGY }}$; the values for fat (43 to $56 \%$ ) were higher than those for protein (40 to $47 \%$ ), reflecting the greater variability of milk lipids. The correlations between the overall recoveries (total solids and energy content) were strong (96\% both on raw data and residuals). The correlations between all $\% \mathrm{CY}$ and $\mathrm{REC}_{\mathrm{FAT}}$ and $\mathrm{REC}_{\mathrm{PROTEIN}}$ yielded low (\%CYWATER) to medium values (13 to $+48 \%$ ), whereas those with $\mathrm{REC}_{\text {SOLIDS }}$ and $\mathrm{REC}_{\text {ENERGY }}$ exhibited stronger relationships (55 to $96 \%$ ).

The Pearson and residual correlations between dCY were near $100 \%$, which was to be expected given that these traits were calculated by multiplying \% CY with daily milk yield. The correlations differed between the raw data and the residuals for the relationships between $\mathrm{dCY}$ and $\% \mathrm{CY}$; they were negative or not significant $(-23$ to $8 \%)$ for the raw data, but moderately positive (15 to $42 \%$ ) for the residuals. Similar results were found for the relationships between $\mathrm{dCY}$ and the recoveries (i.e., negative or null among raw data and moderately positive among residuals); when the raw data were correlated, a significant and positive relationship was found only between $\mathrm{dCY}_{\text {SOLIDS }}$ and $\mathrm{REC}_{\text {PROTEIN }}$.

The Pearson product-moment correlation coefficients between the cheese-making and milk quality traits (components, casein index, and SCS) are presented in Table 4. Milk total solids, fat, protein, and casein were highly and positively associated with \%CY (52 to 97\%; $P<0.001)$; moderately associated with $\mathrm{REC}_{\mathrm{FAT}}$ and $\mathrm{REC}_{\text {PRoteIn }}$ (24 to 56\%); highly associated with RECsolids and $\mathrm{REC}_{\text {ENERGY }}$ (69 to $92 \%$ ); negatively associated with dMY ( -40 to $-20 \%)$; and were independent of or had slightly negative associations with dCY $(-29$ to $+12 \%$ ). The casein number and lactose content were independent or slightly associated with \%CY ( -8 to $-29 \%$ ); had slight positive correlations with $\mathrm{REC}_{\mathrm{PRO}}$ TEIN (15 and $17 \%$, respectively); were negatively associated with the other REC ( -11 to $-44 \%)$; and were highly and positively associated with $\mathrm{dMY}$ and $\mathrm{dCY}$ (54 to $61 \%$ ). Lastly, the correlations of SCS with the various cheese-making traits were slightly lower and opposite in sign with respect to the casein number and lactose content.

\section{Factors Affecting \%CY, REC, and dCY}

Table 5 shows the results from the linear model used to explain the importance of the tested effects on cheese-making traits. The stage of lactation had the highest influence on the $\% \mathrm{CY}$; these traits showed linear increases $(P<0.001$; estimated by orthogonal contrasts) during lactation (Figure 2a), with maximum differences between the first and last least squares means of $6.5,4.5$, and $2.5 \%$ for $\% \mathrm{CY}_{\mathrm{CURD}}, \% \mathrm{CY}_{\text {SOLIDS }}$, and $\% \mathrm{CY}_{\mathrm{WATER}}$, respectively. These differences empha- 


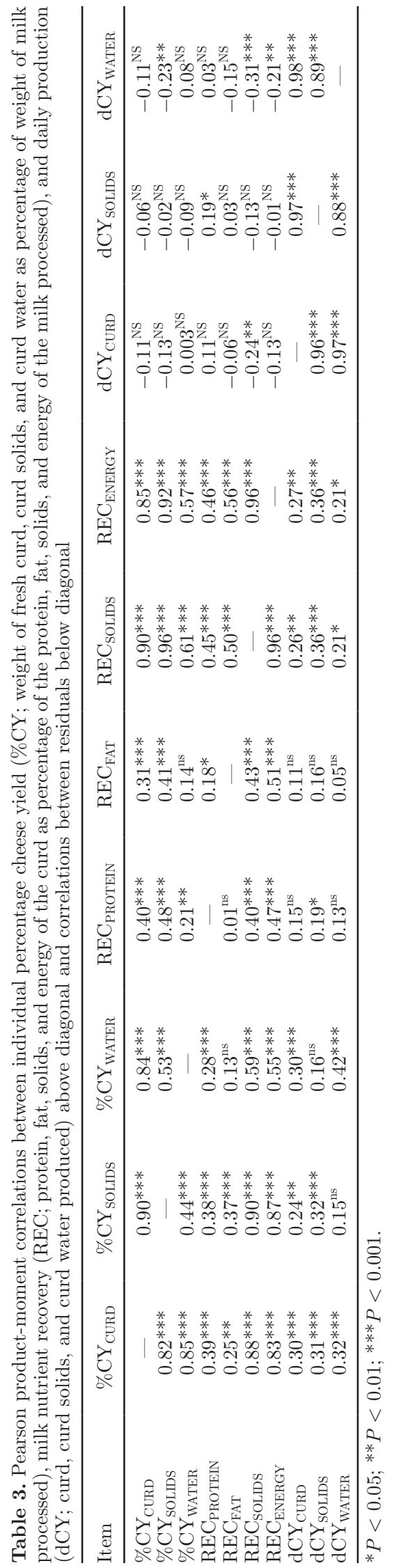

sized that the variability of $\% \mathrm{CY}_{\mathrm{CURD}}$ was more highly influenced by the curd retention of DM compared with water. Parity and dMY did not significantly affect these traits, though we did find that the $\% \mathrm{CY}$ values tended to be higher for primiparous (Table 6) and for low-milk-producing buffaloes (Table 7). Moreover, as shown in Table 5, HTD explained about $15 \%$ of the variability for all \%CY.

For milk nutrient recoveries in the curd, parity did not have any significant effect, although primiparous buffaloes significantly outperformed multiparous buffaloes for $\mathrm{REC}_{\text {SOLIDS }}$ and $\mathrm{REC}_{\text {ENERGY }}$ (Table 6). Days in milk affected $\mathrm{REC}_{\text {PROTEIN }}, \mathrm{REC}_{\mathrm{SOLIDS}}$, and $\mathrm{REC}_{\mathrm{EN}-}$ ERGY $(P<0.001)$. As presented in Figures $2 \mathrm{~b}$ and $2 \mathrm{c}$, these traits tended to show linear increases during buffalo lactation, whereas $\mathrm{REC}_{\mathrm{FAT}}$ was relatively constant. Daily milk production influenced $\mathrm{REC}_{\text {PROTEIN }}$ $(P<0.01)$, with medium- to high-producing animals showing greater recoveries of this nutrient compared with low-producing animals (linear contrast; $P<0.05$ ). The difference between the highest and the lowest least squares means (second and fifth classes, respectively) was $3.0 \%$. The recoveries of DM and energy were found to be affected by dMY $(P<0.001$ and $P<0.01$, respectively), with the recovery tending to be lower for medium- and high-producing buffaloes. In the case of REC, HTD effect explained different proportions of the variance, ranging from $22 \%$ for $\mathrm{REC}_{\mathrm{SOLIDS}}$ to $54 \%$ for $\mathrm{REC}_{\mathrm{FAT}}$. The stage of lactation was the most important source of variation $(P<0.001)$ for all production traits (Table 5). For dMY, we observed a linear $(P<0.05)$ decrease during lactation, whereas $\mathrm{dCY}$ yielded higher values for the second class (60-109 d from calving), reflecting increases in \%CY. Moreover, dCY were not affected by order of parity, and the proportions of the variance explained by HTD for these traits had values close to those found for dMY (18\%). In general, the reproducibility among the 24 different vats was highly satisfactory; the effect of this term was nonsignificant for all of the studied cheese-making traits.

\section{DISCUSSION}

\section{Cheese Yield of Buffalo Milk}

The average \%CY (25.6\%) observed in the present study is identical to that previously reported when the predictive formula of Altiero et al. (1989) was applied to individual buffalo milk samples $(25.6 \%$; Rosati and Van Vleck, 2002). Zicarelli et al. (2007a) previously used a model cheese-manufacturing method $(1.5 \mathrm{~L}$ of milk per sample) to make actual individual-level assessments of $\% \mathrm{CY}_{\mathrm{CURD}}$ for 320 lactating buffaloes. The authors separated the animals into 2 groups based on the ratio 
Table 4. Pearson product-moment correlations between individual percentage cheese yield (\%CY; weight of fresh curd, curd solids, and curd water as percentage of weight of milk processed), milk nutrient recovery (REC; protein, fat, solids, and energy of the curd as percentage of the protein, fat, solids, and energy of the milk processed), daily production (dCY; curd, curd solids, and curd water produced), and milk composition

\begin{tabular}{|c|c|c|c|c|c|c|c|}
\hline Trait & $\begin{array}{c}\mathrm{TS}, \\
\%\end{array}$ & $\begin{array}{c}\text { Fat, } \\
\%\end{array}$ & $\begin{array}{c}\text { Protein, } \\
\%\end{array}$ & $\begin{array}{c}\text { Casein, } \\
\%\end{array}$ & $\underset{\%}{\text { Casein no., }}$ & $\begin{array}{c}\text { Lactose } \\
\%\end{array}$ & $\begin{array}{l}\text { SCS, }{ }^{1} \\
\text { units }\end{array}$ \\
\hline \multicolumn{8}{|c|}{ Cheese yield, \% } \\
\hline$\% \mathrm{CY}_{\mathrm{CURD}}$ & $0.90^{* * *}$ & $0.85^{* * *}$ & $0.75^{* * *}$ & $0.78^{* * *}$ & $-0.06^{\mathrm{NS}}$ & $-0.29^{* * *}$ & $0.06^{\mathrm{NS}}$ \\
\hline$\% \mathrm{CY}_{\text {WATER }}$ & $0.97^{* * *}$ & $0.94^{* * *}$ & $0.76^{* * *}$ & $0.78^{* * *}$ & $-0.08^{\mathrm{NS}}$ & $-0.23^{* *}$ & $0.02^{\mathrm{NS}}$ \\
\hline \multicolumn{8}{|c|}{ Nutrient recovery, $\%$} \\
\hline REC $_{\text {PROTEIN }}$ & $0.50^{* * *}$ & $0.40^{* * *}$ & $0.44^{* * *}$ & $0.56^{* * *}$ & $0.15^{*}$ & $0.17^{*}$ & $-0.12^{\mathrm{NS}}$ \\
\hline \multicolumn{8}{|c|}{ Production trait, $\mathrm{kg} / \mathrm{d}$} \\
\hline Milk yield & $-0.41^{* * *}$ & $-0.40^{* * *}$ & $-0.47^{* * *}$ & $-0.20^{*}$ & $0.59^{* * *}$ & $0.60^{* * *}$ & $-0.31^{* * *}$ \\
\hline $\mathrm{dCY}_{\mathrm{CURD}}$ & $-0.13^{\mathrm{NS}}$ & $-0.13^{\mathrm{NS}}$ & $-0.21^{* *}$ & $0.07^{\mathrm{NS}}$ & $0.61^{* * *}$ & $0.55^{* * *}$ & $-0.34^{* * *}$ \\
\hline $\mathrm{dCY}_{\text {SOLIDS }}$ & $-0.01^{\mathrm{NS}}$ & $0.002^{\mathrm{NS}}$ & $-0.16^{*}$ & $0.12^{\mathrm{NS}}$ & $0.59^{* * *}$ & $0.55^{* * *}$ & $-0.36^{* * *}$ \\
\hline $\mathrm{dCY}_{\text {WATER }}$ & $-0.23^{* *}$ & $-0.22^{* *}$ & $-0.26^{* * *}$ & $0.002^{\mathrm{NS}}$ & $0.59^{* * *}$ & $0.54^{* * *}$ & $-0.28^{* * *}$ \\
\hline
\end{tabular}

${ }^{1} \mathrm{SCS}=\log _{2}(\mathrm{SCC} \times 100,000)+3$.

$* P<0.05 ; * *<0.01 ; * * *<0.001$.

between the predicted $\% \mathrm{CY}_{\mathrm{CURD}}$ (using the prediction formula of Altiero et al., 1989) and the protein content (high and low) of the milk. They obtained $\% \mathrm{CY}_{\mathrm{CURD}}$ values of 26.5 and $25.2 \%$ for buffaloes of the 2 groups; this was found to reflect a between-group difference in milk fat content (8.99 and 8.45\%, respectively).

As mentioned above, most Italian buffalo milk is processed to produce Mozzarella di Bufala Campana. The $\% \mathrm{CY}_{\mathrm{CURD}}$ of this unique buffalo-derived PDO dairy product is about $25 \%$, and its production requires milk with fat and protein contents of at least 7.2 and $4.2 \%$, respectively, according to the PDO regulations. Often, Mozzarella di Bufala Campana cheese has a water content higher than that found in the present study. This reflects that we chose not to mimic the production of mozzarella through the "pasta filata" technology, but rather used a simpler and more common cheese-making method that allowed us to compare the results to those from commercialized dairy products of other species, and to use a relatively small quantity of milk per model cheese $(500 \mathrm{~mL})$.

In the present study (Table 2), we obtained a much higher $\% \mathrm{CY}_{\text {CURD }}$ from buffalo milk $(+71 \%)$ than that previously obtained in a similar study using individual milk samples from dairy cows (Brown Swiss breed; Bittante et al., 2013a). Obviously this difference is largely related to the higher fat and protein contents of buffalo milk with respect to cow milk $(+4.2$ and +1.1 per-

Table 5. Results from ANOVA ( $F$-value and significance) for individual percentage cheese yield (\%CY; weight of fresh curd, curd solids, and curd water as a percentage of weight of milk processed), milk nutrient recovery (REC; protein, fat, solids, and energy of the curd as percentage of the protein, fat, solids, and energy of the milk processed), daily production (dCY; curd, curd solids, and curd water produced)

\begin{tabular}{|c|c|c|c|c|c|c|}
\hline Trait & DIM & Parity & Vat/WB & $d M Y^{1}$ & $\mathrm{HTD}^{2}, \%$ & $\mathrm{RMSE}^{3}$ \\
\hline \multicolumn{7}{|c|}{ Cheese yield, \% } \\
\hline$\% \mathrm{CY}_{\mathrm{CURD}}$ & $7.27^{* * *}$ & $1.49^{\mathrm{NS}}$ & $0.90^{\mathrm{NS}}$ & $1.78^{\mathrm{NS}}$ & 15 & 2.92 \\
\hline$\% \mathrm{CY}_{\text {SOLIDS }}$ & $11.60^{* * *}$ & $1.56^{\mathrm{NS}}$ & $1.28^{\mathrm{NS}}$ & $1.81^{\mathrm{NS}}$ & 17 & 1.58 \\
\hline \multicolumn{7}{|c|}{ Nutrient recovery, \% } \\
\hline REC $_{\text {PROTEIN }}$ & $5.74^{* * *}$ & $1.14^{\mathrm{NS}}$ & $0.87^{\mathrm{NS}}$ & $3.16^{* *}$ & 23 & 1.84 \\
\hline $\mathrm{REC}_{\mathrm{FAT}}$ & $1.07^{\mathrm{NS}}$ & $1.75^{\mathrm{NS}}$ & $0.89^{\mathrm{NS}}$ & $0.82^{\mathrm{NS}}$ & 54 & 1.37 \\
\hline Milk yield & $18.51^{* * *}$ & $2.90^{*}$ & - & - & 18 & 2.29 \\
\hline $\mathrm{dCY}_{\mathrm{CURD}}$ & $6.56^{* * *}$ & $0.48^{\mathrm{NS}}$ & $0.88^{\mathrm{NS}}$ & - & 22 & 0.58 \\
\hline $\mathrm{dCY}_{\text {SOLIDS }}$ & $5.06^{* * *}$ & $0.21^{\mathrm{NS}}$ & $0.94^{\mathrm{NS}}$ & - & 26 & 0.29 \\
\hline $\mathrm{dCY} \mathrm{YATER}_{\text {WAT }}$ & $7.29 * * *$ & $0.82^{\mathrm{NS}}$ & $0.78^{\mathrm{NS}}$ & - & 21 & 0.31 \\
\hline
\end{tabular}

${ }^{1} \mathrm{dMY}=$ daily milk yield $(\mathrm{kg} / \mathrm{d})$.

${ }^{2}$ Herd/test day effect expressed as proportion of variance explained by herd/test date calculated by dividing the corresponding variance component by the total variance.

${ }^{3} \mathrm{RMSE}=$ root means square error.

${ }^{*} P<0.05 ;{ }^{* *} P<0.01 ;{ }^{* * *} P<0.001$. 

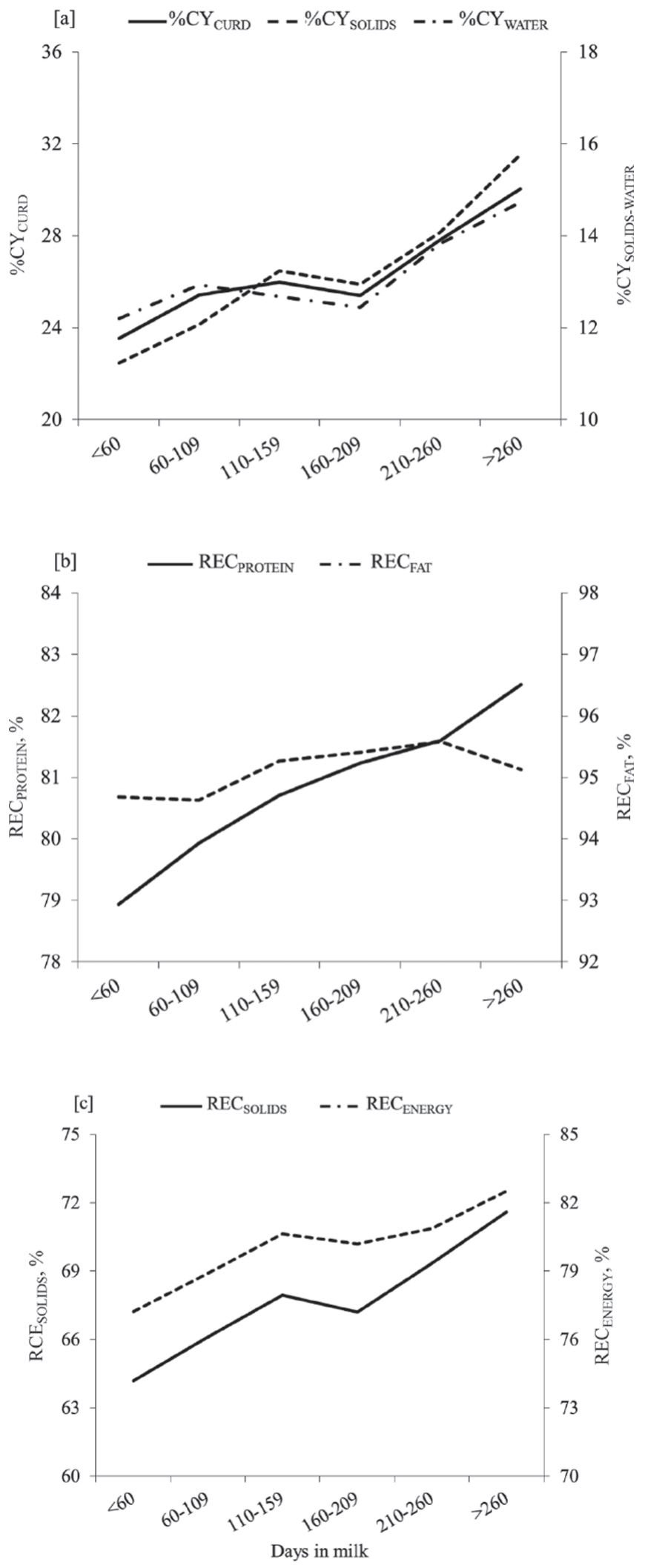

Figure 2. Least squares means of cheese yield (\% $\mathrm{CY}_{\mathrm{CURD}}$, $\left.\% \mathrm{CY}_{\text {SOLIDS }}, \% \mathrm{CY}_{\text {WATER }} ; \mathrm{a}\right)$, milk nutrient recovery (REC $\mathrm{R}_{\text {PROTEIN }}$, $\mathrm{REC}_{\mathrm{FAT}}$; $\mathrm{b}$, and $\mathrm{REC}_{\mathrm{SOLIDS}}, \mathrm{REC}_{\mathrm{ENERGY}}$; $\mathrm{c}$ ) over days in milk. centage units, respectively). The efficiencies of cheesemaking from the milk of these 2 species appear to be similar; the average ratio between the weight of cheese obtained and the quantity of fat plus protein in the milk processed was $\sim 1.92$ for buffaloes and $\sim 1.85$ for cows. This difference reflected the milk fat:milk protein ratios found in the 2 studies (1.78 and 1.17 for buffalo and cow, respectively), the recoveries of milk fat and protein in the curd, and the retention of water in the curd. For $\% \mathrm{CY}_{\mathrm{CURD}}$, the ratios of $\mathrm{DM}$ to water retained in the curd were 0.95 and $0.89 \mathrm{~kg}$ of cheese solids per $\mathrm{kg}$ of milk fat+protein for buffaloes and cows, respectively, whereas the ratios of water retained in the curd per unit of milk fat+protein were 0.97 and 0.96 , respectively. Auldist et al. (2004) used a similar approach to compare bulk milk (with or without standardization of the milk protein:fat ratio) from Jersey versus Friesian dairy cows.

The correlations we obtained between $\% \mathrm{CY}$ and milk components (Table 4) were similar to those reported for cows (Bittante et al., 2013a), confirming a close link between milk component percentages and \%CY in these species. Buffaloes had greater variabilities than cows with respect to the $\% \mathrm{CY}$; the SD for the buffalo results were $\sim 2$-fold higher than those of cows for $\% \mathrm{CY}$ CURD and $\% \mathrm{CY}_{\text {SOLIDS }}$, and 1.5-fold higher for $\% \mathrm{CY}_{\text {WATER }}$ (Table 2). This reflected the much higher variability of the milk components (\%) in Italian Mediterranean buffaloes (Cecchinato et al., 2012) compared with cows, especially in the case of fat content.

The $\% \mathrm{CY}$ showed linear increases of $\sim 3 \%$ units during lactation (Figure 2). This is consistent with the results obtained by Potena et al. (2001) for buffalo milk and by Cipolat-Gotet et al. (2013) for individual bovine milk samples. Similar to the results from a previous survey (Tiezzi et al., 2009), the buffaloes in the present study showed a linear decrease in daily milk production $(\mathrm{kg} / \mathrm{d}$; data not shown) but corresponding increases in the fat and protein contents; this would appear to explain the trend observed for \%CY. In both studies, the effect of lactation stage was evaluated using models that included dMY; thus, the effects on \%CY and the milk fat and protein contents cannot be attributed to the lactation-related production decrease. In cow milk, numerous authors have reported that $\% \mathrm{CY}_{\mathrm{CURD}}$ increases during lactation, both for bulk (Kefford et al., 1995; Auldist et al., 1996; Coulon et al., 1998) and individual (Wedholm et al., 2006) milk samples (albeit without correcting for dMY). Auldist et al. (1996) reported that the effect of the final lactation period was higher for cows that had higher milk SCCs $\left(>5 \times 10^{5} /\right.$ $\mathrm{mL}$ ) compared with healthy cows (SCC $\left.<2 \times 10^{5} / \mathrm{mL}\right)$. In the present work, we did not observe any correlation between \%CY and SCS in buffaloes (Table 3) in ac- 
Table 6. Effect of parity (LSM and $P$-values of contrast between primiparous and multiparous buffalo cows ${ }^{1}$ ) on individual percentage cheese yield (\% CY; weight of fresh curd, curd solids, and curd water as percentage of weight of milk processed), milk nutrient recovery (REC; protein, fat, solids, and energy of the curd as percentage of the protein, fat, solids, and energy of the milk processed), and daily production (dCY; curd, curd solids, and curd water produced)

\begin{tabular}{|c|c|c|c|c|c|c|}
\hline \multirow[b]{2}{*}{ Trait } & \multicolumn{5}{|c|}{ Parity $(\mathrm{P})$} & \multirow{2}{*}{$\frac{\text { Contrast, } P \text {-value }}{\text { P1 vs. P2-P5 }}$} \\
\hline & 1 & 2 & 3 & 4 & 5 & \\
\hline \multicolumn{7}{|l|}{ Cheese yield, \% } \\
\hline$\% \mathrm{CY}_{\mathrm{CURD}}$ & 27.5 & 26.8 & 25.6 & 25.8 & 26.2 & $3.97^{*}$ \\
\hline$\% \mathrm{CY}_{\text {SOLIDS }}$ & 13.7 & 13.5 & 12.6 & 13.2 & 13.1 & $2.65^{\mathrm{NS}}$ \\
\hline$\% \mathrm{CY}_{\text {WATER }}$ & 13.4 & 13.5 & 13.0 & 12.6 & 13.2 & $0.82^{\mathrm{NS}}$ \\
\hline $\mathrm{REC}_{\mathrm{FAT}}$ & 95.2 & 95.4 & 94.5 & 95.3 & 95.2 & $0.13^{\mathrm{NS}}$ \\
\hline $\mathrm{REC}_{\text {SOLIDS }}$ & 69.4 & 67.8 & 66.6 & 67.3 & 67.6 & $6.19^{*}$ \\
\hline REC $_{\text {ENERGY }}$ & 81.0 & 80.0 & 79.3 & 80.0 & 79.9 & $4.32^{*}$ \\
\hline \multicolumn{7}{|l|}{ Production trait, $\mathrm{kg} / \mathrm{d}$} \\
\hline Milk yield & 6.53 & 6.74 & 8.22 & 6.88 & 7.69 & $3.34^{\mathrm{NS}}$ \\
\hline $\mathrm{dCY}_{\mathrm{CURD}}$ & 1.82 & 1.83 & 1.99 & 1.80 & 1.92 & $0.22^{\mathrm{NS}}$ \\
\hline $\mathrm{dCY}_{\text {SOLIDS }}$ & 0.94 & 0.89 & 0.97 & 0.92 & 0.94 & $0.03^{\mathrm{NS}}$ \\
\hline
\end{tabular}

${ }^{1}$ The contrasts between pluriparous parities were never significant.

Significance of contrasts: ${ }^{*} P<0.05$; ${ }^{* *} P<0.01$; ${ }^{* *} P<0.001$.

cordance with what found by Potena et al., (2007). The negative relationships between daily milk production and the $3 \% \mathrm{CY}$ (Table 7 ), which were obtained with a statistical model that also included the stage of lactation, showed that the difference in daily production had a much lower effect on \% CY than the stage of lactation corrected for dMY. The differences in \% CY between the highest and the lowest classes of dMY were -3.7 , -1.7 , and $-1.2 \%$, respectively, for $\% \mathrm{CY}_{\mathrm{CURD}}, \% \mathrm{CY}$ SOLIDS, and $\% \mathrm{CY}_{\text {WATER }}$, whereas those between the first and the last periods of lactation were $-6.5,-4.5$, and $-2.5 \%$, respectively. For the parity effect (Table 6 ), we observed small differences for \%CY, in favor of younger animals; this is consistent with previous findings in dairy cows (Cipolat-Gotet et al., 2013).

Finally, Table 5 shows the how much of the \%CY variances $(\%)$ that were explained by HTD. This effect reflects the variance associated with the farm sampled (i.e., differences in micro-climates, feeding systems, and herd management), as well as any variability related to the day of milk sampling/analysis. Our results in buffaloes were slightly lower than those previously obtained in cows by Cipolat-Gotet et al. (2013).

\section{Buffalo Milk Nutrient Recoveries in the Curd}

The variabilities of milk nutrient recoveries in the curd and cheese composition had not previously been investigated in buffalo milk at the individual level. In the case of bovine bulk milk, the sources of variation, which include the coagulation properties (Bynum and Olson, 1982), milk quality (Ikonen et al., 1999;
Verdier-Metz et al., 2001), breed (Banks et al., 1986; Malacarne et al., 2006), season (Summer et al. 2003), and feeding regimen (Banks et al., 1986; Kefford et al., 1995; Verdier-Metz et al., 1998), have been extensively studied for individual milk components (casein/ protein and fat) and the overall (DM) recovery in the curd. In some of these previous studies, however, the milk was partially defatted before processing to achieve the specific fat:protein ratio needed for the type of cheese produced. If this standardization of the milk fat:protein ratio reduced $\% \mathrm{CY}$ by decreasing the milk fat content, the recoveries of milk components in the curd, especially $\mathrm{REC}_{\mathrm{FAT}}$, would be highly affected. The direct processing of individual milk samples without any pretreatments, as done in the present study, should more fully preserve the variability that is directly related to the animal and its rearing environment. Using individual samples of raw full-fat milk, Cipolat-Gotet et al. (2013) examined the phenotypic variabilities of the REC, whereas Bittante et al. (2013a) observed that these traits could potentially be used (together with \%CY) for the genetic improvement of cows for the cheese-making aptitude of their milk. Currently, milk components (\% fat and \% protein) are used as traits for the indirect genetic selection of dairy breeds, in efforts to improve \%CY (VanRaden, 2004; Miglior et al., 2005); this implicitly assumes that their recoveries in curd/losses in whey are constant. In the case of the Italian Mediterranean buffalo, the PKM index (which predicts the kilograms of mozzarella produced per lactation) is also included in the selection index; the mozzarella yield $(\mathrm{kg})$ is estimated by a predictive 


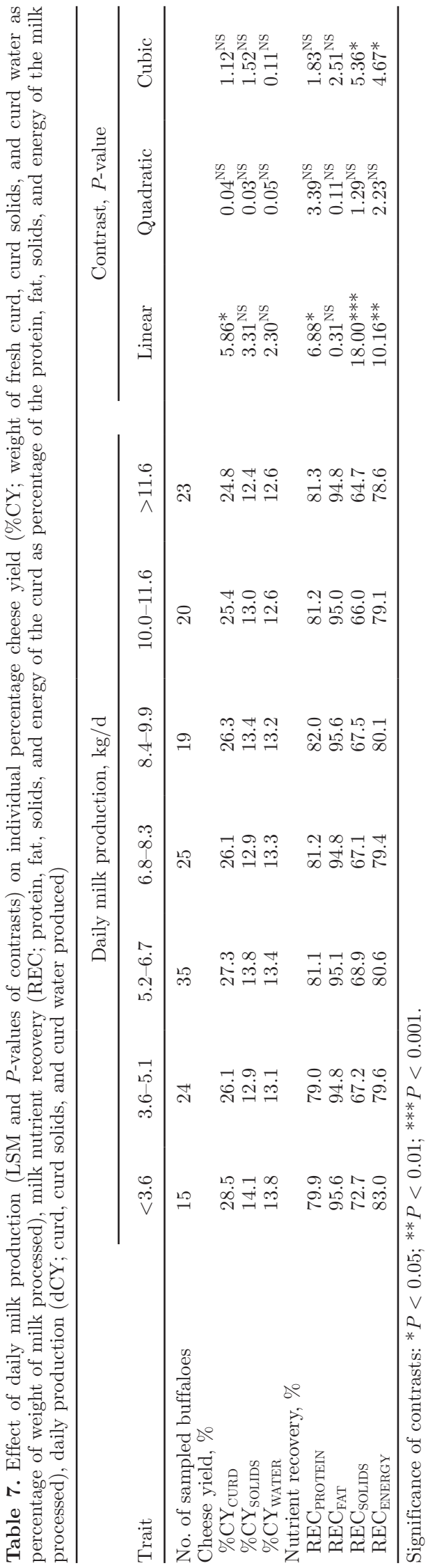

formula (Altiero et al., 1989) that uses knowledge of the milk protein and fat contents and assumes that the recoveries of these components in the curd are constant. When individual Brown Swiss milk samples were processed, however, the retentions of these milk components in the curd were not constant, and they were clearly influenced by genetic factors (Bittante et al., 2013a). Moreover, the previous study found low or nonsignificant phenotypic and genetic correlations between the fat and protein contents of cow milk and their percentages of recovery in the curd. The present study of buffalo milk showed that the nutrient recoveries were not constant, and the variabilities were much larger than those observed during the processing of cow milk (Table 2). Furthermore, these traits were affected by factors that are strictly related to the animal and its environment (Table 5).

Buffalo milk is characterized by higher fat and protein contents (Zicarelli, 2004; Bonfatti et al., 2012a; Cecchinato et al., 2012) compared with cow milk, and the present study shows that buffalo milk is associated with greater recoveries of all nutrients in the curd (Table 2), with $\mathrm{REC}_{\text {PROTEIN }}, \mathrm{REC}_{\mathrm{FAT}}, \mathrm{REC}_{\mathrm{SOLIDS}}$, and $\mathrm{REC}_{\text {ENERGY }}$ found to be $2.3,5.3,14.8$, and 12.1 percentage units higher in buffalo milk, respectively. Given the correlations between the fat and protein contents and REC (Table 4), these differences could be partly explained by the higher fat and protein contents of buffalo milk. The milk and cheese differences between cows and buffaloes are likely to be at least partly explained by differences in their protein profiles. In buffalo milk, a higher casein content, a higher casein number, and different proportions among the protein fractions govern the formation of a coagulum with a higher curd firmness during the cheese-making process (Cecchinato et al., 2012). In cow milk, Bynum and Olson (1982) observed that higher values of $\mathrm{REC}_{\mathrm{PROTEIN}}$ and $\mathrm{REC}_{\mathrm{FAT}}$ were associated with higher coagulum firmness. Consistent with this, the milk produced by Italian Mediterranean buffaloes is characterized by high curd firmness (Zicarelli et al., 2001; Bonfatti et al., 2012b; Cecchinato et al., 2012). In a review of studies on the modeling and genetics of milk coagulation properties, Bittante et al. (2012) emphasized that the patterns of milk coagulation, curd firming, and syneresis are very different between buffalo milk and cow milk, as in the case of small ruminant milk, suggesting the need for a different modeling strategy and parameters that can wholly depict the process regardless of species (Bittante, 2011; Bittante et al., 2013b, 2014). Moreover, buffalo milk is characterized by larger fat globules than bovine milk, which could result in an easier physical entrapment of fat within the casein network formed during the coagulation process. Consistent with this, our raw data showed a positive 
correlation between fat and protein recovery in the curd (18\%, Table 4$)$.

The differences in $\mathrm{REC}_{\text {SOLIDS }}$ and $\mathrm{REC}_{\text {ENERGY }}$ between the 2 major dairy species were higher than the differences between the $\mathrm{REC}_{\text {PROTEIN }}$ and $\mathrm{REC}_{\mathrm{FAT}}$. This reflects that the milk lactose content, which is almost totally lost in whey, is very similar among different species, but represents a greater proportional loss in the case of milk with lower fat and protein contents (cow milk) compared with more concentrated milk (buffalo milk). The effects of the lactose dilution and whey loss on total milk solids explains the strong favorable correlations of $\mathrm{REC}_{\text {SOLIDS }}$ and $\mathrm{REC}_{\text {ENERGY }}$ with the total solid, fat, protein, and casein contents of buffalo milk (Table 4). This lactose dilution effect also explains the increases in $\mathrm{REC}_{\text {SOLIDS }}$ and $\mathrm{REC}_{\text {ENERGY }}$ during lactation, and their decreases with increased milk yield in buffalo. In contrast, $\mathrm{REC}_{\mathrm{FAT}}$ was not influenced by any fixed effect included in the model. Lactation seemed to strongly influence the recovery of protein in the curd, which increased linearly in buffaloes from calving to the end of the milk production phase. In a study evaluating the effects of DIM, parity, and dMY on the detailed milk protein compositions of Mediterranean buffalo milk at the individual level (Bonfatti et al., 2012a), the whey protein $(\mathrm{g} / \mathrm{L})$ content was found to be higher at the beginning and end of lactation, whereas the casein $(\mathrm{g} / \mathrm{L})$ content did not change appreciably; the resulting casein index (whey protein/casein, \%) therefore showed low variability during lactation. Using bulk defatted milk, Kefford et al. (1995) failed to find any difference in $\mathrm{REC}_{\mathrm{FAT}}$ or $\mathrm{REC}_{\text {PROTEIN }}$ between medium- and late-lactation cows, but they observed higher values for $\mathrm{REC}_{\text {SOLIDS }}$ in milk produced at the end of lactation. In contrast, Auldist et al. (1996) obtained lower values for $\mathrm{REC}_{\mathrm{PROTEIN}}$ and $\mathrm{REC}_{\mathrm{FAT}}$ from late-lactation cows producing milk with high SCC $\left(>5 \times 10^{5} / \mathrm{mL}\right)$. In this study, we failed to find any relationship between SCS and the studied cheese-making traits (Table 3).

Using individual bovine milk samples, Cipolat-Gotet et al. (2013) observed that $\mathrm{REC}_{\text {PROTEIN }}$ was highly influenced by the order of parity, showing lower values for older cows. Bonfatti et al. (2012a) found higher values for the casein index among younger buffaloes, reflecting a greater decrease of total casein than whey protein among older buffaloes. In the present study, we did not observe any clear decrease of $\mathrm{REC}_{\text {PROTEIN }}$ with increasing buffalo age (Table 7).

\section{CONCLUSIONS}

In this study, we used a model cheese-manufacturing procedure to assess the cheese-making efficiency of in- dividual-level milk samples from Italian Mediterranean buffaloes. The method appeared to be reproducible for most of the traits assessed during the cheese-making process, and allowed us to assess the individual variability of buffaloes for these traits. The buffalo species had high \%CY, reflecting the high concentrations of milk components that are directly involved in curd formation. In fact, buffalo milk showed great recovery of both individual (protein and fat) and overall (DM and energy) milk nutrients in the curd, despite having a high fat:protein ratio. All of the recoveries determined in this study were nonconstant and showed good variability. Among the tested factors, DIM had the most influence on \%CY, showing trends similar to those observed in dairy cows. Overall nutrient recoveries were also affected by DIM. Daily milk production showed a positive relationship with $\mathrm{REC}_{\text {PROTEIN. }}$

The dCY define the quantity of cheese $(\mathrm{kg} / \mathrm{d})$, also in terms of DM and water retained in the curd, produced daily by lactating dairy animals and could represent the real income of dairy buffaloes, given that most of the milk produced by this species is processed into cheese, often directly by farmers. These traits reflect a combination of daily milk production, the concentrations of nutrients in milk, and their recoveries in cheese. As expected, the mean values obtained for this species were much lower than those observed for dairy cows. Compared with Brown Swiss cows, the daily yields of buffaloes were only $31 \%$ in fluid milk, $53 \%$ in fresh curd, and $55 \%$ in cheese solids. However, the lower production of buffaloes is compensated by their overall greater longevity, lower feed energy requirement, lower protein requirement, and the much higher prices commanded by their products (in Italy, buffalo milk and mozzarella cheese are about 3 -fold and 2-fold more expensive than the corresponding products from cows). Together, these factors make buffalo economically competitive with other dairy species and explain the tendency for growth among the current buffalo populations.

The results presented herein improve our understanding of the variabilities of and relationships among different cheese yields, recovery traits, daily milk production levels, and milk components measured from individual buffaloes.

\section{ACKNOWLEDGMENTS}

The authors thank the technical staff at the breeders associations of Treviso and Padova provinces and the Friuli-Venezia Giulia region for providing milkrecording data and assisting in data collection, and the managers of the seven sampled dairy farms for their collaboration. 


\section{REFERENCES}

Ali, A. K. A., and G. E. Shook. 1980. An optimum transformation for somatic cell concentration in milk. J. Dairy Sci. 63:487-490.

Altiero, V., L. Moio, and F. Addeo. 1989. Previsione della resa in mozzarella sulla base del contenuto in grasso e proteine del latte di bufala. Sci. Tecn. Latt. Cas. 40:425-433.

ANASB (National Breeders Association of Buffalo Species). 2013. National production statistics. Accessed Nov. 7, 2014. http://www. anasb.it/home.htm.

Auldist, M. J., S. Coats, B. J. Sutherland, J. J. Mayes, and G. H. McDowell. 1996. Effects of somatic cell count and stage of lactation on raw milk composition and the yield and quality of cheddar cheese. J. Dairy Res. 63:269-280.

Auldist, M. J., K. A. Johnston, N. J. White, W. P. Fitzsimons, and M. J. Boland. 2004. A comparison of the composition, coagulation characteristics and cheesemaking capacity of milk from Friesian and Jersey dairy cows. J. Dairy Res. 71:51-57.

Banks, J. M., W. Banks, D. D. Muir, and A. G. Wilson. 1981. Cheese yield: Composition does matter. Dairy Ind. Int. 46:15-22.

Banks, J. M., L. J. Clapperton, D. D. Muir, and A. K. Girdler. 1986. The influence of diet and breed of cow on the efficiency of conversion of milk constituents to curd in cheese manufacture. J. Sci. Food Agric. 37:461-468.

Bittante, G. 2011. Modeling rennet coagulation time and curd firmness of milk. J. Dairy Sci. 94:5821-5832.

Bittante, G., C. Cipolat-Gotet, and A. Cecchinato. 2013a. Genetic parameters of different measures of cheese yield and milk nutrient recovery from an individual model cheese-manufacturing process. J. Dairy Sci. 96:7966-7979.

Bittante, G., B. Contiero, and A. Cecchinato. 2013b. Prolonged observation and modelling of milk coagulation, curd firming, and syneresis. Int. Dairy J. 29:115-123.

Bittante, G., E. Pellattiero, F. Malchiodi, C. Cipolat-Gotet, M. Pazzola, G. M. Vacca, S. Schiavon, and A. Cecchinato. 2014. Quality traits and modeling of coagulation, curd firming and syneresis of sheep's milk of Alpine breeds fed diets supplemented with rumen protected conjugated fatty acid (CLA). J. Dairy Sci. 97:40184028.

Bittante, G., M. Penasa, and A. Cecchinato. 2012. Invited review: Genetics and modeling of milk coagulation properties. J. Dairy Sci. 95:6843-6870.

Bonfatti, V., M. Gervaso, A. Coletta, and P. Carnier. 2012a. Effect of parity, days in milk, and milk yield on detailed milk protein composition in Mediterranean water buffalo. J. Dairy Sci. 95:42234229.

Bonfatti, V., M. Giantin, M. Gervaso, A. Coletta, M. Dacasto, and P. Carnier. 2012b. Effect of CSN1S1-CSN3 ( $\alpha$ S1- $\kappa$-casein) composite genotype on milk production traits and milk coagulation properties in Mediterranean water buffalo. J. Dairy Sci. 95:3435-3443.

Bynum, D. G., and N. F. Olson. 1982. Influence of curd firmness at cutting on Cheddar cheese yield and recovery of milk constituents. J. Dairy Sci. 65:2281-2290.

Cecchinato, A., M. Penasa, C. Cipolat Gotet, M. De Marchi, and G. Bittante. 2012. Short communication: Factors affecting coagulation properties of Mediterranean buffalo milk. J. Dairy Sci. 95:1709-1713.

Cipolat-Gotet, C., A. Cecchinato, M. De Marchi, and G. Bittante. 2013. Factors affecting variation of different measures of cheese yield and milk nutrients recovery from an individual model cheese manufacturing process. J. Dairy Sci. 96:7952-7965.

Cologna, N., R. Dal Zotto, M. Penasa, L. Gallo, and G. Bittante. 2009 A laboratory micro-manufacturing method for assessing individual cheese yield. Ital. J. Anim. Sci. 8(Suppl. 2):393-395.

Coulon, J. B., I. Verdier, P. Pradel, and M. Almena. 1998. Effect of lactation stage on the cheese making properties of milk and the quality of Saint-Nectaire-type cheese. J. Dairy Res. 65:295-305.

Di Palo, R., R. Napolano, A. Potena, G. Galiero, G. Fusco, B. Gasparrini, and F. Zicarelli. 2007. Relationship among the cheese yield, the characteristics of the curd and those of buffalo milk. Ital. J. Anim. Sci. 6(Suppl. 2):1096-1099.
Emmons, D. B., C. A. Ernstrom, C. Lacroix, and P. Verret. 1990 Predictive formulas for yield of cheese from composition of milk: A review. J. Dairy Sci. 73:1365-1394.

FAOSTAT. 2014. Food and Agriculture Organization of the United Nations (FAO) statistical database. Accessed Aug. 21, 2014. http://faostat.fao.org/site/291/default.aspx.

Ferragina, A., C. Cipolat-Gotet, A. Cecchinato, and G. Bittante. 2013. The use of Fourier-transform infrared spectroscopy to predict cheese yield and nutrient recovery or whey loss traits from unprocessed bovine milk samples. J. Dairy Sci. 96:7980-7990.

Ikonen, T., O. Ruottinen, E.-L. Syväoja, K. Saarinen, E. Pahkala, and M. Ojala. 1999. Effect of milk coagulation properties of herd bulk milks on yield and composition of Emmental cheese. Agric. Food Sci. Finl. 8:411-422.

Kefford, B., M. P. Christian, B. J. Sutherland, J. J. Mayes, and C. Grainger. 1995. Seasonal influences on Cheddar cheese manufacture: Influence of diet quality and stage of lactation. J. Dairy Res. $62: 529-537$.

Malacarne, M., A. Summer, E. Fossa, P. Formaggioni, P. Franceschi, M. Pecorari, and P. Mariani. 2006. Composition, coagulation properties and Parmigiano-Reggiano cheese yield of Italian Brown and Italian Friesian herd milks. J. Dairy Res. 73:171-177.

Miglior, F., B. L. Muir, and B. J. Van Doormaal. 2005. Selection indices in Holstein cattle of various countries. J. Dairy Sci. 88:12551263

Napolano, R., A. Potena, G. Iovane, A. Coletta, G. Campanile, G. Neglia, and L. Zicarelli. 2007. Relationships between Italian Mediterranean Buffalo milk compounds. Ital. J. Anim. Sci. 6(Suppl. 2):1088-1091.

NRC. 2001. Nutrient Requirements of Dairy Cattle. 7th rev. ed. Natl. Acad. Press, Washington, DC.

Potena, A., C. De Filippo, D. Bove, T. Cocca, T. Haubner, and L. Zicarelli. 2001. Resa alla caseificazione e parametri reologici del latte bufalino: Risultati preliminari su latti individuali. Pages 236-240 in Proc. 1st Ital. national Congr. Buffalo Breeding, Eboli, Italy.

Potena, A., R. Napolano, G. Galiero, A. Coletta, R. Di Palo, G. Neglia, and L. Zicarelli. 2007. Relationship between lactodinamographic and characteristics of buffalo milk. Ital. J. Anim. Sci. 6(Suppl. 2):1084-1087.

Rosati, A., and L. D. Van Vleck. 2002. Estimation of genetic parameters for milk, fat, protein and Mozzarella cheese production for the Italian river buffalo Bubalus bubalis population. Livest. Prod. Sci. $74: 185-190$.

Summer, A., P. Franceschi, A. Bollini, P. Formaggioni, F. Tosi, and P. Mariani. 2003. Seasonal variations of milk characteristics and cheesemaking losses in the manufacture of Parmigiano-Reggiano cheese. Vet. Res. Commun. 27(Suppl. 1):663-666.

Tiezzi, F., A. Cecchinato, M. De Marchi, L. Gallo, and G. Bittante. 2009. Characterization of buffalo production of northeast Italy. Ital. J. Anim. Sci. 8(Suppl. 3):160-162.

Van Slyke, L. L., and W. V. Price. 1952. Cheese. Orange-Judd Publ. Co., New York, NY.

VanRaden, P. M. 2004. Invited review: Selection on net merit to improve lifetime profit. J. Dairy Sci. 87:3125-3131.

Verdier-Metz, I., J. B. Coulon, and P. Pradel. 2001. Relationship between milk fat and protein contents and cheese yield. Anim. Res. 50:365-371.

Verdier-Metz, I., J. B. Coulon, P. Pradel, C. Viallon, and J. L. Berdaguè. 1998. Effect of forage conservation (hay or silage) and cow breed on the coagulation properties of milk and on the characteristics of ripened cheese. J. Dairy Res. 65:9-21.

Wedholm, A., L. B. Larsen, H. Lindmark-Mansson, A. H. Karlsson, and A. Andren. 2006. Effect of protein composition on the cheesemaking properties of milk from individual dairy cows. J. Dairy Sci. 89:3296-3305

Zicarelli, L. 2004. Buffalo milk: Its properties, dairy yield and mozzarella production. Vet. Res. Commun. 28(Suppl. 1):127-135.

Zicarelli, L., G. Neglia, R. Napolano, M. Di Rubbio, C. Caso, B. Gasparrini, and R. Di Palo. 2007a. Correction of the ratio between real cheese yield at 28 hours and protein according to chemical composition of buffalo milk. Ital. J. Anim. Sci. 6(Suppl. 2):1108-1111. 
Zicarelli, L., A. Potena, C. De Filippo, R. Di Palo, and G. Campanile. 2001. Confronto tra bufale con differente resa alla caseificazione. Pages 241-246 in Proc. 1st Ital. national Congr. Buffalo Breeding, Eboli, Italy.
Zicarelli, L., A. Potena, M. Di Rubbio, A. Coletta, C. Caso, B. Gasparrini, and R. Di Palo. 2007b. Estimation of buffalo cheese yield by using the chemical-physical parameters of the milk. Ital. J. Anim. Sci. 6(Suppl. 2):1100-1103. 